\title{
PENGARUH PEMBERIAN FERMENTASI COMPLETE FEED BERBASIS PAKAN LOKAL TERHADAP KONSUMSI, KONVERSI PAKAN, DAN FEED COST KAMBING BLIGON JANTAN
}

\section{THE EFFECT OF FERMENTED COMPLETE FEED BASED ON LOCAL FEED RESOURCES ON CONSUMPTION, FEED CONVERSION AND FEED COST OF MALE BLIGON GOATS}

\author{
Lucky Latifah Munawaroh $^{\text {* }}$, I Gede Suparta Budisatria², dan Bambang Suwignyo² \\ ${ }^{1}$ Dinas Peternakan dan Perikanan, Magetan, 63351 \\ ${ }^{2}$ Fakultas Peternakan, Universitas Gadjah Mada, Yogyakarta, 55281
}

Submitted: 19 December 2014, Accepted: 18 June 2015

\section{INTISARI}

Penelitian bertujuan untuk mengetahui pengaruh pemberian complete feed yang difermentasi terhadap konsumsi, konversi pakan, dan feed cost kambing Bligon jantan. Penelitian dilaksanakan selama dua belas minggu di kandang individual kelompok tani Purwo Manunggal Panggang, Gunung Kidul. Ternak yang digunakan adalah kambing Bligon jantan sebanyak 15 ekor dengan kisaran bobot awal 12-15 kg dengan rerata umur 8 bulan yang dibagi dalam tiga perlakuan dan lima ulangan. Ketiga perlakuan tersebut adalah: perlakuan $1\left(R_{1}\right)$, merupakan perlakuan kontrol; perlakuan $2\left(R_{2}\right)$, kambing diberi pakan complete feed yang difermentasi satu minggu; dan perlakuan $3\left(R_{3}\right)$, kambing diberi pakan complete feed yang difermentasi dua minggu. Data yang diambil meliputi konsumsi, konversi pakan, dan feed cost per gain. Data dianalisis statistik dengan analisis variansi Rancangan Acak Lengkap pola searah dan dilanjutkan dengan uji Duncan's Multiple Range Test. Hasil penelitian menunjukkan bahwa konsumsi bahan kering, bahan organik, protein kasar, serat kasar, lemak kasar, dan total digestible nutrients secara nyata dipengaruhi oleh perlakuan pakan. Rerata konsumsi $B K$ pada $R_{0}, R_{1}$, dan $R_{2}$ adalah $81,18 \pm 22,30$, $43,29 \pm 6,26$, dan $49,52 \pm 5,912 \mathrm{~g} / \mathrm{kg} \mathrm{BB}^{0,75}$, sedangkan konsumsi protein kasar dan TDN berturut-turut adalah $13,05 \pm 3,58,4,76 \pm 0,68,4,30 \pm 0,98$, dan $57,57 \pm 15,8,36,22 \pm 5,23,42,67 \pm 5,09$. Perlakuan pakan berpengaruh tidak nyata terhadap pertambahan konversi pakan dan feed cost per gain. Hal ini dapat disimpulkan bahwa pemberian pakan complete feed yang difermentasi tidak meningkatkan konsumsi nutrien tetapi mampu menghasilkan kinerja kambing Bligon yang setara dengan pakan kontrol.

(Kata kunci: Bahan pakan lokal, Complete feed, Feed cost, Fermentasi, Kambing Bligon jantan, Konsumsi, Konversi pakan)

\section{ABSTRACT}

The aim of the research was to identify the effect of fermented complete feed on consumption, feed conversion and feed cost of male Bligon goats. The research was conducted for twelve weeks in the individual housing of goat farmers at Purwo Manunggal farmers' group, Panggang, Gunungkidul District. Fifteen male at eight months old Bligon goats with initial body weight of 12 to $15 \mathrm{~kg}$, were randomly divided into three groups, each group was consisted of five male goats. The treatments were: 1) control feed ( $\left.R_{0}\right)$, 2) one week fermented complete feed $\left(R_{1}\right)$ and 3) two weeks fermented complete feed $\left(R_{2}\right)$. The variables were consisted of feed intakes, feed conversion, and feed cost per gain. One Way analysis of variance was used to analyze the mean differences and continued with Duncan's Multiple Range Test for significant differences. The result showed that the intakes of dry matter, organic matters, crude protein, crude fiber, crude fat, and total digestible nutrients were significantly $(P<0.05)$ affected by treatments, goat fed with control feed had higher intakes compared to goats fed with one week and two weeks fermented complete feed. The average of dry matter intake for $R_{0}, R_{1}$, and $R_{2}$ were $81.18 \pm 22.30,43.29 \pm 6.26$ and $49.52 \pm 5.912 \mathrm{~g} / \mathrm{kg} \mathrm{BB} \mathrm{B}^{0.75}$, while crude protein and total digestible nutrients intakes were 13.05 \pm 3.58 ,

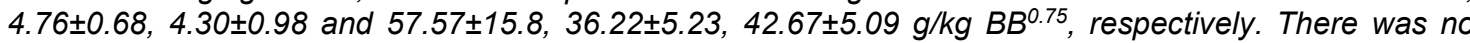
significant effect of feed treatments were found on feed conversion and feed cost per gain. It could be concluded that either one or two week fermentation of complete feed did not increase nutrient consumption but give similar impact compare to goat with control feed.

(Key words: Consumption, Feed conversion, Feed cost, Fermented complete feed, Local feed resources, Male Bligon goats)

\footnotetext{
* Korespondensi (corresponding author):

Telp. +62 8565909 3222, E-mail: luckeyluph@gmail.com
} 


\section{Pendahuluan}

Kambing Bligon merupakan kambing lokal Indonesia yang mempunyai keistimewaan dari segi reproduksinya, yaitu mampu memproduksi cempe sepanjang tahun, tidak dipengaruhi musim, dan mempunyai tingkat prolifikasi yang relatif tinggi. Kinerja ternak kambing sangat dipengaruhi faktor genetik dan faktor lingkungan. Faktor genetik merupakan faktor yang dibawa ternak sejak lahir dan merupakan faktor turunan dari induk, sedangkan faktor lingkungan merupakan faktor yang ada di sekitar ternak seperti pakan, penyakit, tata laksana, dan iklim (Haryanto et al., 1997).

Pemanfaatan sumber daya lokal, termasuk bahan pakan secara maksimal merupakan langkah strategis dalam mencapai efisiensi produksi kambing. Keragaman bahan baku pakan yang tinggi menawarkan fleksibilitas yang tinggi bagi peternak, namun juga menawarkan kompleksitas bagi nutrisionis agar dapat dimanfaatkan secara efisien. Dari segi kuantitas, maka pakan lokal berserat tinggi (materi lingoselulosa) merupakan yang terbesar. Beberapa kendala dalam pemanfaatan hasil sisa tanaman adalah 1) palatabilitas rendah, 2) nilai nutrisi rendah, 3) penanganan relatif sulit (pengeringan, penggilingan, transportasi, dan penyimpanan), dan 4) ketersediaan musiman. Salah satu cara yang dapat dilakukan untuk mengatasi permasalahan pakan di Gunung Kidul, terutama pada musim kering adalah dengan fermentasi pakan menggunakan Biofit ${ }^{\circledR}$ sebagai inokulum. Complete feed adalah salah satu bentuk pemberian pakan kepada ternak. Pemberian pakan dengan sistem complete feed akan terhindar dari seleksi pakan sehingga sebagian besar bagian pakan akan dapat dikonsumsi dan cenderung tidak selektif saat makan. Hijauan dan konsentrat yang digunakan dalam complete feed yaitu pakan lokal yang terdiri dari daun gamal, tebon jagung, klobot jagung, batang pisang, daun jati, gaplek, bekatul, dan pollard.

Penggunaan pakan komplit pada sapi yang sedang laktasi memang sangat relevan untuk memudahkan pemenuhan kebutuhan nutrisi (terutama energi) yang sangat tinggi, dan pada saat yang sama mampu menyumbang kebutuhan serat (NDF) yang sangat penting bagi stabilisasi ekosistem rumen. Selain itu, pakan komplit juga lebih menjamin meratanya distribusi asupan harian ransum, agar fluktuasi kondisi ekosistem di dalam rumen diminimalisir (Tafaj et al., 2007).

Penggunaan bahan pakan lokal untuk complete feed diharapkan dapat meminimalisir biaya pakan karena menggunakan bahan pakan yang sudah tersedia di sekitar tempat tinggal peternak tanpa harus membeli dan melaui proses fermentasi juga diharapkan dapat meningkatkan nilai nutrisi complete feed itu sendiri. Salah satu cara untuk meningkatkan kecernaan hijauan pakan lokal yang umumnya mempunyai kandungan serat yang tinggi dan kadar protein yang rendah adalah dengan melakukan fermentasi pakan menggunakan Biofit $^{\circledR}$ sebagai inokulum. Biofit ${ }^{\circledR}$ yang mengandung multimikrobia seperti bakteri selulolitik, proteolitik, dan amilolitik diduga dapat meningkatkan nilai nutrisi pakan lokal yang akan difermentasi. Fermentasi merupakan salah satu teknologi untuk meningkatkan nilai gizi pakan berserat tinggi. Complete feed dengan bahan pakan lokal melaui proses fermentasi juga diharapkan dapat meningkatkan nilai nutrisi complete feed itu sendiri di samping menunjang produktivitas ternak.

\section{Materi dan Metode}

\section{Materi}

Ternak percobaan yang digunakan dalam penelitian ini adalah ternak kambing Bligon jantan sebanyak 15 ekor dengan kisaran bobot badan 12 sampai $15 \mathrm{~kg}$ dengan umur rerata 8 bulan yang dibagi dalam tiga perlakuan dan lima ulangan, kemudian dikelompokkan berdasarkan bobot badan. Dalam satu kelompok mendapatkan perlakuan pakan yang berbeda. Ransum yang digunakan dalam penelitian ini adalah complete feed yang bersumber dari beberapa jenis bahan pakan lokal. Bahan pakan lokal terdiri atas tebon, kulit jagung, gamal, pollard, ketela, batang pisang, dedak padi serta molases dan Biofit ${ }^{\circledR}$.

Perlakuan yang digunakan dalam penelitian ini adalah $\mathrm{R}_{0}$ yang merupakan pakan kontrol yaitu daun gamal dan pakan yang umum digunakan oleh peternak, $R_{1}$ merupakan complete feed yang difermentasi 1 minggu, perlakuan $\mathrm{R}_{2}$ merupakan complete feed yang difermentasi 2 minggu. Kandungan nutrien bahan penyusun complete feed seperti tersaji pada Tabel 1. 
Tabel 1. Susunan dan kandungan ransum (ration and content of feed)

\begin{tabular}{lrrr}
\hline \multicolumn{1}{c}{ Bahan pakan (\%) (feed ingredients (\%)) } & $\mathrm{R}_{0}$ & $\mathrm{R}_{1}$ & $\mathrm{R}_{2}$ \\
\hline Daun gamal (gamal leaves) & 75 & 20 & 20 \\
Tebon jagung (corn straw) & - & 20 & 20 \\
Kulit jagung (cornhusk) & - & 3 & 3 \\
Ketela pohon (cassava) & - & 6 & 6 \\
Daun jati (teak leaves) & 15 & 3 & 3 \\
Batang pisang (banana stems) & - & 12 & 12 \\
Pollard & 6 & 6 & 6 \\
Dedak padi (rice bran) & 3 & 3 & 3 \\
Mineral & 1 & 0,29 & 0,29 \\
Molasses & - & 1,20 & 1,20 \\
Biofit & - & 0,01 & 0,01 \\
Air (water) & - & 25,50 & 25,50 \\
\hline Total & 100 & 100 & 100 \\
\hline Kandungan nutrien ransum (\%) (nutrient content of dietary (\%)) & 16,08 & 11,00 & 11,57 \\
$\quad$ Protein kasar (crude protein) & 18,82 & 9,65 & 8,11 \\
$\quad$ Serat kasar (crude fiber) & 2,76 & 1,01 & 0,65 \\
$\quad$ Lemak kasar (extract ether) & 9,22 & 3,35 & 2,82 \\
$\quad$ Abu (ash) & & & \\
\hline $\mathrm{R}_{0}$ : ransum kontrol (control feed); $\mathrm{R}_{1}:$ complete feed fermentasi 1 minggu (one week fermented complete feed),
\end{tabular}

\section{Pembuatan fermentasi complete feed}

Pembuatan complete feed dilakukan dengan mengumpulkan bahan pakan yang digunakan kemudian dihaluskan menggunakan hammer mill dengan ukuran terbesar sampai $0,5 \mathrm{~cm}$. Bahan pakan yang telah dihaluskan, dihamparkan di atas terpal kemudian dibasahi dengan Biofit ${ }^{\circledR}$, dicampur dengan air dan diaduk rata sampai homogen dengan proporsi tebon jagung $32 \%$, kulit jagung $5 \%$, gamal $30 \%$, daun jati $6 \%$, ketela pohon $6 \%$, dedak $3 \%$, batang pisang $12 \%$, molases $1 \%$, Biofit ${ }^{\circledR} 10 \mathrm{cc}$, air 1,5 liter, dan mineral 0,2 gr. Semua bahan pakan yang telah dicampur membentuk complete feed dan difermentasi selama 1-2 minggu. Hasil fermentasi complete feed selama 1-2 minggu siap digunakan sebagai pakan lengkap dan diberikan pada ternak percobaan.

Semua jenis pakan fermentasi yang akan digunakan diambil sampel untuk dianalisis komposisi bahan kering dan bahan organiknya. Ternak kambing penelitian ditimbang, dikelompokkan berdasarkan bobot badan, kemudian ditempatkan pada masingmasing kandang untuk dilakukan adaptasi terhadap pakan dan kondisi lingkungan. Setiap kelompok terdiri dari 5 (lima) ekor ternak dan mendapatkan perlakuan jenis pakan yang berbeda.

\section{Rancangan percobaan}

Percobaan menggunakan Rancangan Acak Kelompok yang terdiri atas 3 perlakuan dan 5 ulangan (blok/kelompok). Perubah yang diukur dalam penelitian ini adalah konsumsi nutrien $\left(\mathrm{g} / \mathrm{kg} \mathrm{BB}^{0,75}\right)$, konversi pakan, dan feed cost per gain. Data dianalisis Oneway Anova dengan bantuan software personal komputer Statistical Product and Service Solution (SPSS) seri 17.

\section{Hasil dan Pembahasan}

Rerata konsumsi nutrien pakan kambing yang diberi perlakuan pakan berbeda dapat dilihat pada Tabel 2 .

\section{Konsumsi bahan kering}

Hasil analisis statistik menunjukkan bahwa perbedaan perlakuan pakan berpengaruh $(P<0,05)$ terhadap konsumsi bahan kering (BK). Kambing pada perlakuan $R_{0}$ mengkonsumsi BK lebih tinggi dibandingkan dengan kambing yang diberi complete feed fermentasi satu dan dua minggu. BK pada $R_{1}$ dan $R_{2}$ menunjukkan perbedaan yang tidak nyata, hal ini disebabkan karena complete feed fermentasi 1 dan 2 minggu mempunyai kandungan BK yang hampir sama.

Kandungan rerata BK pada $\mathrm{R}_{0}$ lebih tinggi disebabkan oleh pakan basal yang berupa gamal, daun jati serta konsentrat mempunyai kandungan PK dan TDN yang lebih tinggi dibanding pakan complete feed. Perlakuan $\mathrm{R}_{1}$ dan $\mathrm{R}_{2}$ didominasi bahan pakan dari limbah pertanian, sehingga palatabilitas rendah walaupun bahan pakan ditambah dengan molasses agar memiliki aroma yang disukai ternak. 
Perbedaan jenis bahan pakan penyusun ransum dapat menimbulkan perbedaan palatabilitas dan kandungan nutrisi yang pada akhirnya menyebabkan perbedaan jumlah pakan yang dikonsumsi oleh ternak. Hal ini sesuai dengan pendapat Parakkasi (1999) bahwa tinggi rendahnya konsumsi dipengaruhi oleh palatabilitas pakan.

\section{Konsumsi bahan organik}

Berdasarkan analisis statistik, rerata konsumsi bahan organik (BO) menunjukkan perbedaan yang nyata $(P<0,05)$. Konsumsi $\mathrm{BO}$ pada $\mathrm{R}_{0}$ lebih tinggi karena konsumsi $\mathrm{BK}$ juga lebih tinggi dibanding $\mathrm{R}_{1}$ dan $\mathrm{R}_{2}$. Kamal (1994) menyatakan bahwa konsumsi BO berkorelasi positif dengan konsumsi BK, hal ini disebabkan karena zat-zat yang terkandung dalam BO terdapat pula pada BK. Tillman et al. (1991) menyatakan bahwa BO terdiri dari lemak kasar, protein kasar, serat kasar, dan bahan ekstrak tanpa nitrogen (BETN). Ketersediaan BO dalam pakan yang masuk ke dalam tubuh ternak penting artinya untuk mensuplai kebutuhan nutrisi bagi ternak.

Konsumsi BO pada complete feed fermentasi hasil penelitian ini lebih rendah jika dibandingkan dengan konsumsi BO pada penelitian Kamalidin (2012) yang menggunakan complete feed fermentasi KBK $699,41 \mathrm{~g} / \mathrm{ekor} / \mathrm{hari}$.

\section{Konsumsi protein kasar}

Analisis statistik menunjukkan bahwa perlakuan yang diberikan berpengaruh secara nyata $(P<0,05)$ pada konsumsi protein kasar (PK). Hal ini disebabkan karena jenis pakan dan kandungan PK pakan yang diberikan juga berbeda, yaitu $R_{0} 16,08 \%, R_{1} 11,00 \%$, dan $R_{2}$ 11,57 sehingga akan mempengaruhi konsumsi PK. Kandungan PK pada pakan $\mathrm{R}_{0}$ lebih tinggi dibandingkan dengan complete feed fermentasi. Hal ini disebabkan karena pakan yang digunakan untuk menyusun complete feed fermentasi berupa limbahlimbah pertanian yang mengandung PK rendah.

Konsumsi PK pada complete feed fermentasi hasil penelitian ini berkisar antara 37,28 sampai 71,00 g/ekor/hari hampir sama dengan hasil penelitian Triwahyudi (2012) yakni antara 61,51 sampai 90,57 g/ekor/hari. Devendra dan Burns (1994) menyatakan bahwa kebutuhan protein dicerna pada kambing berkisar antara 0,45 sampai $0,64 \mathrm{~g} / \mathrm{kg}$ dari bobot badannya. Kambingkambing yang digunakan dalam penelitian memiliki rerata bobot $13,26 \mathrm{~kg}$, sehingga kebutuhan konsumsi PK berkisar 5,67 sampai 8,07 g/ekor/hari. Hal ini menunjukkan bahwa konsumsi PK tersebut sudah memenuhi kebutuhan kambing, sehingga complete feed fermentasi dapat digunakan.

\section{Konsumsi serat kasar}

Hasil analisis statistik menunjukkan bahwa perlakuan yang diberikan berpengaruh secara nyata $(P<0,05)$ terhadap konsumsi serat kasar (SK). Konsumsi SK yang berbeda nyata antar perlakuan disebabkan karena kandungan SK pakan juga berbeda. Pakan Ro mengandung SK 18,83\% sedangkan complete feed fermentasi 9,65\%. Complete feed yang difermentasi mempunyai kandungan SK yang rendah disebabkan oleh pengaruh fermentasi pakan. Hal ini sesuai dengan pendapat Laconi (1998) bahwa fermentasi adalah proses perubahan kimiawi yang terjadi pada suatu bahan akibat dari aktivitas suatu mikroorganisme yang bertujuan untuk menyederhanakan struktur selulosa.

Tabel 2. Konsumsi nutrien kambing Bligon ( $\left.\mathrm{g} / \mathrm{kg} \mathrm{BB}^{0,75}\right)$ (consumption nutrient Bligon goats $\left(\mathrm{g} / \mathrm{kg} \mathrm{BB}{ }^{0,75}\right)$ )

\begin{tabular}{lccc}
\hline \hline \multicolumn{1}{c}{ Konsumsi (consumption) } & $\mathrm{R}_{0}$ & $\mathrm{R}_{1}$ & $\mathrm{R}_{2}$ \\
\hline Konsumsi total (total consumption) & 786,33 & 648,33 & 712 \\
Bahan kering (dry matter) & $81,18 \pm 22,30^{\mathrm{a}}$ & $67,79 \pm 14,75^{\mathrm{b}}$ & $72,30 \pm 20,29^{\mathrm{b}}$ \\
Bahan organik (organic matter) & $77,20 \pm 21,27^{\mathrm{a}}$ & $39,80 \pm 6,81^{\mathrm{b}}$ & $46,53 \pm 5,66^{\mathrm{b}}$ \\
Protein kasar (crude protein) & $13,05 \pm 3,58^{\mathrm{a}}$ & $4,76 \pm 0,68^{\mathrm{b}}$ & $4,30 \pm 0,98^{\mathrm{b}}$ \\
Serat kasar (crude fiber) & $15,28 \pm 4,19^{\mathrm{a}}$ & $4,17 \pm 0,60^{\mathrm{b}}$ & $4,01 \pm 0,47^{\mathrm{b}}$ \\
Lemak kasar (extract ether) & $2,24 \pm 0,61^{\mathrm{a}}$ & $0,43 \pm 0,06^{\mathrm{b}}$ & $0,32 \pm 0,03^{\mathrm{b}}$ \\
Total digestible nutrients & $57,57 \pm 15,8^{\mathrm{a}}$ & $36,22 \pm 5,23^{\mathrm{b}}$ & $42,67 \pm 5,09^{\mathrm{b}}$ \\
\hline
\end{tabular}

$\mathrm{R}_{0}$ : ransum kontrol (control feed), $\mathrm{R}_{1}$ : complete feed fermentasi 1 minggu (one week fermented complete feed), $\mathrm{R}_{2}$ : complete feed fermentasi 2 minggu (two week fermented complete feed).

a,b Superskrip yang berbeda pada baris yang sama menunjukkan perbedaan nyata $(P<0,05)($ different superscripts at the same row indicate significant differences $(P<0.05)$ ). 


\section{Konsumsi lemak kasar}

Hasil analisis statistik menunjukkan bahwa perlakuan yang diberikan berpengaruh $(P<0,05)$ terhadap konsumsi lemak kasar (LK). Kandungan LK pada perlakuan $\mathrm{R}_{0}$ lebih besar dibandingkan dengan perlakuan pakan $\mathrm{R}_{1}$ dan $\mathrm{R}_{2}$. Penurunan LK pada complete feed yang difermentasi disebabkan karena bakteri menggunakan LK sebagai sumber energi.

Konsumsi LK pada complete feed yang difermentasi lebih rendah bila dibandingkan dengan hasil penelitian Kamalidin (2012) dan Munir (2012), yaitu berturut-turut sebesar $1,77 \pm 0,32 \mathrm{~g} / \mathrm{kg} \mathrm{BB}^{0,75}$ dan 1,03 sampai $1,21 \mathrm{~g} / \mathrm{kg} \mathrm{BB}^{0,75}$. Sumadi et al. (1991) menyatakan bahwa bangsa ternak dapat mempengaruhi konsumsi pakan karena kecepatan metabolisme pakan pada setiap bangsa ternak berbeda apabila mendapat pakan dengan kualitas yang sama.

\section{Konsumsi total digestible nutrients}

Hasil analisis statistik menunjukkan bahwa perlakuan yang diberikan berpengaruh $(P<0,05)$ terhadap konsumsi total digestible nutrient (TDN). Perbedaan konsumsi TDN pada penelitian ini dipengaruhi jumlah konsumsi BK dan PK dari masing-masing perlakuan pakan. Ternak yang diberi pakan konvensional mengkonsumsi BK dan PK lebih tinggi dibandingkan dengan ternak yang diberi complete feed fermentasi sehingga nilai konsumsi TDN menjadi tinggi pula. Siregar (1994) menyatakan bahwa banyak sedikitnya konsumsi TDN dipengaruhi oleh kandungan nutrien pakan, karena TDN adalah energi pakan yang dapat dicerna yang berasal dari kandungan nutrien pakan seperti PK, SK, LK, dan BETN.

NRC (1991) menyatakan bahwa kebutuhan TDN domba pada bobot tubuh 10-20 kg dengan pertambahan bobot tubuh 200-250 gr/hari yaitu 0,4-0,8 kg. Rerata konsumsi TDN Ro yaitu 506,58 g/ekor/hari, $R_{1}$ 428,15 g/ekor/hari, dan $\mathrm{R}_{2}$ sebesar 438,53 g/ekor/hari. Konsumsi TDN pada penelitian ini lebih besar dibanding penelitian Triwahyudi (2012) yaitu 417,19 g/ekor/hari, serta hampir sama dengan hasil penelitian Kamalidin (2012) yakni pakan kontrol sebesar 351,08 g/ekor/hari dan complete feed fermentasi sebesar 532,39 g/ekor/hari. Kearl (1982) menyatakan bahwa kebutuhan TDN ternak kambing untuk mencapai pertambahan bobot badan $50 \mathrm{~g} / \mathrm{ekor} / \mathrm{hari}$ adalah $38,05 \mathrm{~g} / \mathrm{kg}$ $\mathrm{BB}^{0,75}$. Dengan demikian konsumsi TDN kambing yang diberi complete feed yang difermentasi pada penelitian telah tercukupi kebutuhannya.

\section{Konversi pakan}

Rerata konversi pakan dan feed cost per gain kambing Bligon yang diberi perlakuan pakan berbeda, dapat dilihat pada Tabel 3.

Hasil analisis statistik menunjukkan bahwa konversi pakan antar perlakuan tidak berbeda nyata. Hal ini menunjukkan bahwa pemanfaatan bahan pakan limbah pertanian yang dicampur menjadi complete feed fermentasi ( $R_{1}$ dan $R_{2}$ ) mempunyai konversi pakan yang hampir sama dengan pakan kontrol $\left(\mathrm{R}_{0}\right)$. Meskipun konsumsi pada complete feed yang difermentasi lebih rendah, namun memiliki nilai konversi yang baik. Berdasarkan nilai tersebut maka nilai konversi yang paling baik yakni pada perlakuan $\mathrm{R}_{1}$. Angka konversi pakan tersebut artinya untuk menaikkan $1 \mathrm{~kg}$ bobot badan, pada $R_{0}$ memerlukan ransum sebanyak 13,01 kg, pada $R_{1}$ memerlukan 9,99 kg, dan pada $R_{2}$ memerlukan $10,15 \mathrm{~kg}$. Meskipun dalam peneltian ini angka konversi yang paling baik pada ransum $\mathrm{R}_{0}$ tetapi ketiganya tidak menunjukkan perbedaan yang nyata.

Hasil penelitian ini lebih rendah dibandingkan hasil penelitian Noviantari (2011) yang menyatakan bahwa rerata konversi pakan kambing Bligon jantan di kelompok ternak Purwo Manunggal sebesar 20,03, tetapi lebih besar jika dibandingkan dengan penelitian Rochmaningtyas (2013) yang mempunyai nilai konversi pakan 12,58 sampai 13,57. Hadi (2008) menyatakan bahwa semakin kecil angka konversi pakan, maka semakin efisien pemanfaatan ransum

Tabel 3. Konversi pakan dan feed cost per gain kambing Bligon (conversion feed and feed cost per gain Bligon goats)

\begin{tabular}{lcrr}
\hline \hline Perlakuan (treatment) & $\mathrm{R}_{0}$ & $\mathrm{R}_{1}$ & $\mathrm{R}_{2}$ \\
\hline Konversi pakan ${ }^{\mathrm{ns}}$ & $13,14 \pm 2,87$ & $10,00 \pm 3,96$ & $10,15 \pm 1,19$ \\
Feed cost per gain ${ }^{\mathrm{ns}}$ & $14311,00 \pm 3188,86$ & $14994,00 \pm 5941,40$ & $15231,00 \pm 1793$ \\
\hline $\mathrm{R}_{0}:$ ransum kontrol (control feed), $\mathrm{R}_{1}$ : complete feed fermentasi 1 minggu (one week fermented complete feed), \\
$\mathrm{R}_{2}:$ complete feed fermentasi 2 minggu (two week fermented complete feed). \\
ns berbeda tidak nyata (non significant).
\end{tabular}


oleh ternak. Siregar (1994) menambahkan bahwa efisiensi ternak ditentukan oleh dua faktor yaitu konsumsi pakan dan pertambahan bobot badan.

Nilai konversi pakan tergantung pada kualitas pakan yang diberikan. Semakin tinggi nutrien yang dikandung akan semakin baik konversi pakan yang dihasilkan. Hal tersebut terjadi karena dengan pakan yang baik maka ternak perlu mengkonsumsi pakan lebih sedikit daripada pakan yang kurang baik. Peningkatan ukuran tubuh memerlukan komponen pembentuknya yaitu air, protein, lemak, karbohidrat, dan mineral. Kadar nutrisi dalam pakan secara tidak langsung akan berperan dalam menentukan nilai konversi pakan. Pond et al. (1995) menyatakan bahwa nutrisi berhubungan langsung dengan laju pertumbuhan dan komposisi tubuh selama pertumbuhan.

\section{Feed cost per gain}

Nilai feed cost per gain dihitung berdasarkan biaya pakan dan bobot badan yang dihasilkan. Hasil analisis statistik antara perlakuan $R_{0}, R_{1}$, dan $R_{2}$ tidak menunjukkan perbedaan yang nyata. Hasil penelitian memberikan indikasi bahwa pemberian pakan complete feed fermentasi dapat menghasilkan feed cost per gain yang sama dibandingkan dengan pakan konvensional, sehingga complete feed dapat dijadikan sebagai pakan alternatif terutama untuk mengatasi masalah pakan pada musim kering.

Safari et al. (2011) menyatakan bahwa ketersediaan hijauan yang bersifat musiman di daerah tropik merupakan masalah teknis yang utama dalam memenuhi kebutuhan akan produk-produk peternakan di masa mendatang. Oleh karena itu, perlu dicari sumber-sumber pakan alternatif. Bakhsi dan Wadhwa (2007) menyatakan bahwa masalah utama pakan pada usaha peternakan terkait dengan musim kering yang panjang, sehingga perlu pakan alternatif seperti complete feed berbahan dasar limbah pertanian untuk mengatasi kelangkaan pakan.

Complete feed fermentasi mempunyai harga yang cukup mahal (Rp1.500/kg) dibandingkan dengan harga pakan kontrol (Rp1.100/kg) sehingga feed cost per gain juga cukup tinggi, walaupun secara statistik tidak menunjukkan perbedaan. Hasil penelitian Kamalidin (2012) mendapatkan nilai feed cost per gain pada domba ekor tipis yang diberi complete feed KBK yang difermentasi sebesar Rp1.1036,11, dengan demikian feed cost per gain yang dihasilkan pada penelitian ini baik, karena memiliki nilai feed cost per gain yang rendah. Beberapa hasil penelitian tentang feed cost per gain menunjukkan bahwa feed cost per gain untuk kambing Bligon adalah Rp16.465,21 (Tahuk, 2008) dan Rp88.150,00 (Sholikhin, 2010).

Basuki (2002) menyatakan bahwa untuk mendapatkan feed cost per gain yang rendah maka pemilihan bahan pakan untuk menyusun ransum harus semurah mungkin dan tersedia secara kontinyu atau dapat juga menggunakan limbah pertanian yang tidak kompetitif. Feed cost per gain dinilai baik apabila angka yang diperoleh serendah mungkin, yang berarti dari segi ekonomi penggunaan pakan efisien.

\section{Kesimpulan}

Berdasarkan hasil penelitian yang dilakukan dapat diambil beberapa kesimpulan bahwa pemberian pakan complete feed yang difermentasi tidak meningkatkan konsumsi nutrien tetapi mampu menghasilkan kinerja kambing Bligon yaitu pertambahan berat badan, konversi pakan, dan feed cost per gain yang sama dengan pakan kontrol yaitu daun gamal, daun jati, pollard, dedak padi, dan mineral. Fermentasi complete feed selama satu dan dua minggu mempunyai dampak terhadap konsumsi dan kinerja yang hampir sama.

\section{Daftar Pustaka}

Bakhsi, M. P. S. and M. Wadhwa. 2007. Tree leaves as complete feed for goat bucks. Small Rumin. Res. 69:74-78.

Basuki, P. 2002. Dasar IImu Ternak Potong dan Kerja. Bahan Ajar. Fakultas Peternakan, Universitas Gadjah Mada, Yogyakarta.

Devendra, C. dan M. Burns. 1994. Produksi Kambing di Daerah Tropis. Penerjemah: IDK Harya Putra. Penerbit Universitas Udayana dan ITB, Bandung.

Hadi, R. F. 2008. Pengaruh pemberian suplementasi protein terhadap konsumsi dan kecernaan nutrien pakan basal jerami kacang tanah. Skripsi Fakultas Peternakan, Universitas Gadjah Mada, Yogyakarta. 
Haryanto, B., I. Inounu, dan I. K. Sutama. 1997. Ketersediaan dan kebutuhan teknologi produksi kambing dan domba. Prosiding Seminar Nasional Peternakan dan Veteriner, Bogor, 7-8 Januari 1997. Pusat Penelitian dan Pengembangan Pertanian, Departemen Pertanian, Bogor .

Kamal, M. 1994. Nutrisi Ternak I. Laboratorium Makanan Ternak, Fakultas Peternakan, Universitas Gadjah Mada, Yogyakarta.

Kamalidin. 2012. Pengaruh formulasi complete feed terhadap kinerja ternak domba ekor tipis. Tesis Fakultas Peternakan, Universitas Gadjah Mada, Yogyakarta.

Kearl, L. C. 1982. Nutrient Requirements of Ruminants in Developing Countries. Published by Internasional Feedstuffs Institute, Utah State University, Logan, Utah.

Laconi, E. B. 1998. Peningkatan mutu pod kakao melalui amoniasi dengan urea dan biofermentasi dengan phanerochaeta chrysosporium serta penjabarannya ke dalam formulasi ransum ruminansia. Disertasi Program Pascasarjana, Institut Pertanian Bogor, Bogor.

Munir, F. F. 2012. Kajian fermentasi kulit buah kakao (Theobroma cacao. L) menggunakan Aspergillus spp terhadap kecernaan dan konsumsi pada kambing Peranakan Ettawa jantan. Disertasi Fakultas Peternakan, Universitas Gadjah Mada, Yogyakarta.

Noviantari, Y. A. 2011. Kinerja kambing Bligon jantan dan betina umur 1 sampai 1,5 tahun di Kelompok Ternak Purwo Manunggal, Dusun Jeruken, Desa Girisekar, Kecamatan Panggang, Gunung Kidul. Skripsi Fakultas Peternakan, Universitas Gadjah Mada, Yogyakarta.

NRC. 1991. Nutrient Requirement of Goats: Angora Dairy, and Meat Goats in Temperate and Tropical Countries. National Academy Press, Washington DC.

Parakkasi, A. 1999. Ilmu Nutrisi dan Makanan Ruminan. Universitas Indonesia Press, Jakarta.

Pond, W. G., D. C. Church and K. R. Pond. 1995. Basic Animal Nutrition and Feeding. $4^{\text {th }}$ edn. John Wileys and Sons Inc. Canada.
Rochmaningtyas, R. N. 2013. Konsumsi dan kecernaan serat kasar dan protein kasar ransum mengandung kulit buah kakao (Theobroma cacao) fermentasi pada kambing bligon jantan. Skripsi Fakultas Peternakan, Universitas Gadjah Mada, Yogyakarta.

Safari, J., D. E. Mushi, L. A. Mtenga, G. C. Kifaro and L. O. Eik. 2011. Growth, carcass and meat quality characteristics of Small East African goats fed straw based diets. Livest. Sci. 135: 168-176.

Sholikhin, W. I. 2010. Perbandingan konsumsi pakan dan pertambahan bobot badan kambing Bligon dan kambing Kejobong jantan. Skripsi Fakultas Peternakan, Universitas Gadjah Mada, Yogyakarta.

Siregar, S. B. 1994. Ransum Ternak Ruminansia. Penebar Swadaya, Jakarta.

Sumadi, N. Ngadiyono, dan Soeparno. 1991. Penampilan produksi sapi Fries Holland, Sumba Ongole, dan Brahman Cross yang dipelihara secara feedlot (penggemukan). Prosiding Seminar Pengembangan Petenakan dalam Menunjang Pembangunan Ekonomi Nasional. Fakultas Peternakan, Universitas Jenderal Sudirman, Purwokerto.

Tafaj , M. Q. Zebeli, C. H. Baes, H. Steingass and W. Drochner. 2007. A metaanalysis examining effects of particle size of total mixed rations on intake, rumen digestion and milk production in high-yielding dairy cows at early lactation. Anim. Feed Sci. Technol. 138: $137-161$

Tahuk, P. K. 2008. Kinerja kambing Bligon jantan pada penggemukan dengan level protein kasar berbeda. Tesis Fakultas Peternakan, Universitas Gadjah Mada, Yogyakarta.

Tillman, A. D., S. Reksohadiprojo, S. Prawirokusumo, S. Lebdosoekojo, dan H. Hartadi. 1991. Ilmu Makanan Ternak Dasar. Gadjah Mada Press, Yogyakarta.

Triwahyudi, E. 2012. Pertambahan bobot badan harian $(\mathrm{PBBH})$ domba Ekor Tipis dengan complete feed mengandung kulit buah kakao (Theobroma cacao L.). Skripsi Fakultas Peternakan, Universitas Gadjah Mada, Yogyakarta. 